кандидат педагогічних наук, доцент

(Полтавський національний педагогічний університет імені В. Г. Короленка) tatablagova@gmail.com

ORCID: 0000-0001-5446-3412

\title{
ФОРМУВАННЯ ПРОФЕСІЙНИХ КОМПЕТЕНТНОСТЕЙ БАЛЕТМЕЙСТЕРА-ПЕДАГОГА У СТРУКТУРІ ВИЩОЇ ХОРЕОГРАФІЧНОЇ ОСВІТИ: ТЕОРЕТИЧНИЙ АСПЕКТ
}

У статті досліджено сутнісні ознаки професї балетмейстера, ї̈ педагогічну ресурсність, основні змістові напрями професійної активності. Схарактеризовано комплекс професійних компетентностей $i$ особистісних якостей балетмейстера-педагога, необхідних для успішної творчої самореалізації у різних формах фахової діяльності; окреслено шляхи їх формування у студентів хореографічних спеціалізаџій у структурі вищої хореографічної освіти.

Ключові слова: балетмейстер, балетмейстер-педагог, хореограф, хореографічна освіта, хореографічна педагогіка, принципи балетмейстерської творчості, виконавський стиль, хореографічно-педагогічна діяльність.

Постановка проблеми. Зміна теоретико-методологічних пріоритетів, освітніх парадигм професійної підготовки студентів-хореографів, упровадження нових держстандартів і освітніх програм у закладах вищої освіти зумовлюють системні й конструктивні зрушення в організації професійного хореографічного навчання. Активізація використання інноваційних підходів і технологій в освітньому просторі вищої хореографічної освіти сфокусована на досягненні сучасної якості навчально-виховного процесу, формуванні у студентів хореографічних спеціальностей різноаспектних фахових компетентностей та значущих особистісних якостей, їх відповідності актуальним і перспективним потребам розвитку усіх освітніх рівнів галузі хореографічної освіти.

Зокрема, в умовах сьогодення актуалізується потреба осмислення мистецтва балетмейстера як творчої професії, визначення пріоритетів іiі розвитку в галузі вищої хореографічної освіти. Діалектика професійних смислів балетмейстерського фаху - у постійній динаміці форм, інноватиці методик, авторських підходів до втілення творчого задуму. 3 урахуванням сучасних соціокультурних тенденцій тлумачення категорії "балетмейстер" передбачає широкі можливості для професійної активності представників зазначеного фаху у різних галузях: вузькоспрямованій мистецькій, дозвіллєвій, педагогічній, спортивній тощо. Балетмейстер має бути лідером у своїй справі, який втілює у мистецтві танцю свою естетику руху, власний почерк, світобачення, є виразником власної педагогічної доктрини, 3 опертям на методологію професії, вивірену часом. Така різноплановість функційних ролей професії призводить до необхідності оволодіння ним цілим спектром видів діяльності: творчо-постановчої, виконавської, управлінської, педагогічної.

Аналіз останніх досліджень і публікацій. Узагальнення наукової, мистецько-педагогічної та творчої спадщини відомих теоретиків і практиків професійної хореографії (Г. Березової, К. Василенка, П. Вірського, В. Вронського, К. Голейзовського, Ю. Григоровича, Ю. Громова, Р. Захарова, Ф. Лопухова, I. Мойсеєва, І. Смірнова, ін.) дозволило схарактеризувати основні змістові напрями балетмейстерської діяльності та, відповідно, специфіку фахової підготовки балетмейстера. Провідні тенденції, організаційно-методичне забезпечення формування компетентностей професії балетмейстера в умовах вищої хореографічної освіти сьогодення розкрито в наукових розвідках сучасних дослідників Л. Андрощук, С. Валукіна, О. Голдрича, С. Забредовського, О. Калініної, Б. Кокуленка, Б. Колногузенка, В. Литвиненка, Л. Макарової, О. Мартиненко, Г. Ніколаї, Т. Павлюк, В. Похиленка, О. Ребрової, Ю. Ростовської, Т. Сердюк, Т. Філановської, Л. Цвєткової, О. Шамрової, М. Юр’євої, ін. Однак, актуальною залишається проблема модернізації професійної підготовки майбутнього фахівцяхореографа в закладах вищої освіти на основі компетентнісного підходу, збагачення хореографічної педагогіки інноваційними ідеями, впровадження сучасних хореографічно-педагогічних технологій у процес викладання професійно-орієнтованих дисциплін.

Мета статті полягає у дослідженні сутнісних ознак, педагогічної ресурсності, напрямів професійної активності балетмейстерського фаху, теоретичному обгрунтуванні компетентнісного підходу до реалізації освітньої програми 3 підготовки фахівців-хореографів у структурі вишів, контент-аналізі змістового наповнення професійно-практичної підготовки студентів закладів вищої хореографічної освіти у контексті стратегій формування комплексу компетентностей балетмейстера-педагога.

Виклад основного матеріалу. Хореографічна діяльність $є$ особливим видом художньої активності, яка виражається в художньому способі сприйняття, пізнання, практичного втілення ідеї засобами організованих рухів людського тіла у просторі відповідно до естетичних принципів та закономірностей розвитку різних стилів і жанрів хореографічного мистецтва. Тож балетмейстерська діяльність, як один із 
iii напрямів, містить і творчо-постановочний, і репетиторський, і педагогічний складники. Широкий спектр професійно значущих компетентностей балетмейстера підтверджує також історична динаміка формування дефініції досліджуваної категорії. Термін балетмейстер, запозичений у першій половині XIX ст. від нім. "ballettmeister" - "постановник, майстер балету", - в енциклопедичних виданнях XX ст. тлумачиться вже як "автор і режисер-постановник балетів, хореографічних творів, дивертисментних номерів (органічних складників в опері та опереті), керівник балетної трупи, що створює систему рухів у сценічному просторі, гармонійно підпорядковуючи танцювальне видовище основній ідеї сценічного мистецького твору" [1: 48]. Узагальнюючи теоретичні напрацювання відомих представників досліджуваного фаху (Г. Алексідзе, А. Ваганової, Ю. Громова, Р. Захарова, Б. Колногузенка, І. Смірнова та ін.), укажемо, що традиційно балетмейстерів поділяють на чотири типи, керуючись змістом їх діяльності: створювач, постановник, репетитор і педагог. Різноаспектна діяльність професії балетмейстера - виконавська, постановча, етнографічно-пошукова, репетиторська, педагогічна, просвітницька - впродовж усього періоду іiі формування загалом визначала стратегії розвитку, зміст, технології, методи роботи, теоретичні і практичні засади хореографічної педагогіки.

Студіювання професійно-практичного досвіду знаних балетмейстерів дозволяє сформулювати головне призначення професії, іiї сутнісні характеристики. "В нашій професії зайвих знань не буває", підкреслює сучасний балетмейстер Б. Колногузенко, інтерпретуючи їі "однією з найцікавіших і водночас найскладніших", яка "вимагає великої кількості умінь, ... професійного володіння та обізнаності в інших мистецтвах, бо саме цей багаж може зробити митця автором сценічного твору, що принесе естетичну насолоду та формуватиме кращі якості людської душі" [2: 5]. Багатофункційність балетмейстерської праці розкриває й дослідниця-мистецтвознавець Т. Павлюк, аналізуючи іï специфіку у проекції становлення української балетної школи: "Унікальність професії полягає у ії функціях, подібних до художника-митця, що відтворює себе, користуючись різноманітними виражальними засобами танцю, сценографії, музики, костюмів. Тому всі дослідники констатують, що балетмейстерське мистецтво віддзеркалює найсуттєвіші художні тенденції і напрямки, стильові, жанрові й естетичні аспекти складного, часто внутрішньо суперечливого поступу сценічного мистецтва" [3: 3]. Отже, балетмейстерську діяльність інтерпретуємо як специфічний вид мистецької активності, складний багатоаспектний феномен в царині професійної хореографії, що втілюється у процесі різновекторної творчої роботи з хореографічним матеріалом: постановчої, пошукової, виконавської, репетиційної, реставраційної, педагогічної.

Змістове наповнення професійних компетентностей балетмейстерства в структурі вищої хореографічної освіти орієнтоване передовсім на формування сукупності сутнісних характеристик, необхідних для практичного застосування у різних напрямах професійної галузі: світоглядно-художньої позиції, індивідуального хореографічного почерку, творчої манери, виконавського стилю, арсеналу засобів сценічної виразності, авторських принципів, методик і технологій хореографічно-педагогічної діяльності. Так, за визначенням О. Шамрової, сучасні умови професійної діяльності висококваліфікованого спеціаліста-хореографа, відкритого до новаторства, творчості, динамічних рішень, вимагають від нього володіння різноаспектними знаннями: загальнокультурологічними, мистецтвознавчими, психолого-педагогічними, менеджерськими та спеціальними хореографічними [4]. Досліджуючи специфіку формування балетмейстерських умінь майбутніх учителів хореографії в умовах вищої школи, О. Пархоменко виокремлює структурні компоненти балетмейстерської діяльності, як-от: мотиваційний (відображає рівень особливих інтересів і захоплень майбутніх учителів хореографії, їх зацікавленість й активну участь у творчій діяльності...), когнітивний (...містить у собі комплекс знань щодо балетмейстерської діяльності), діяльнісно-творчий (розкриває творчі здібності балетмейстера, можливості його самореалізації у професійній діяльності, готовність до балетмейстерської творчості...), операційний (включає комплекс умінь і навичок організації творчої діяльності, способи розумових дій та логічних операцій, а також форми практичної діяльності). При цьому "одним із найскладніших аспектів професійної діяльності балетмейстера" дослідник визначає операційний компонент, мотивуючи це його багатоаспектними характеристиками, серед яких, зокрема, "педагогічні уміння та організаторські здібності" [5: 5-6].

Актуальність упровадження компетентнісного підходу до планування і реалізації освітньої програми 3 підготовки фахівців-хореографів у структурі вишів продиктована системними й комплексними інноваціями в організації вищої хореографічної освіти. Сутність розвитку професійної компетентності студентів хореографічних спеціальностей полягає в активізації їх особистісних і професійних якостей для успішної творчої самореалізації у майбутній фаховій діяльності. Тож перед сучасною хореографічною педагогікою вищої школи постає завдання забезпечення освітнього рівня випускника, що володіє спеціалізованими концептуальними знаннями, здатного до самостійного осмислення i творчого трактування мистецьких процесів, явищ, творів, відкритого до постійного особистісного і професійного самовдосконалення, соціальної та професійної мобільності. 
У цьому контексті переконливою є думка дослідниці Л. Мітакович, яка, зокрема, наголошує, що задля формування педагога-хореографа нового покоління, педагога-гуманіста, хореографа-універсала, дослідника і творця, що володіс переліком затребуваних часом професійних компетенцій, необхідне інноваційне ставлення до процесу професійної підготовки, а також свіже бачення самої освітньої моделі [6: 185-189]. Зокрема, в інтерпретації сучасних учених (Л. Макарової, М. Юр'євої) компетентнісна модель майбутнього педагога-хореографа $є$ результативно-цільовою основою процесу особистісного i професійного розвитку спеціаліста, вираженою системною якістю - компетентністю, що забезпечує його готовність і здатність до продуктивної хореографічної діяльності у професійній сфері [7: 109]. В основі компетентнісної моделі випускника-хореографа, розробленої М. Юр'євою, закладено бінарну класифікацію, що складається 3 двох основних груп компетенцій: універсальних (загальних) i професійних. До першої групи вчена відносить загальнонаукові, загальнокультурні, соціальноособистісні та інструментальні компетенції. Другу (професійну) групу складають загальнопрофесійні та профільно-спеціалізовані компетенції. Кожна із запропонованих груп загалом аргументовано ілюструє багатовимірність процесу фахової підготовки хореографа у вищій школі [8: 51-52]. Дослідниця О. Мартиненко, вважаючи компетентнісний підхід пріоритетним напрямом у професійній підготовці студентів-хореографів у закладах вищої освіти, визначає його таким, що "орієнтує на виконання основних завдань освіти: навчання, самовизначення, самоактуалізацію, соціалізацію та розвиток індивідуальності", також деталізує комплекс педагогічних умов, принципів, організаційних форм, професійно-орієнтованих технологій навчання його успішної реалізації, аналізує профільні компетентності та програмні результати навчання студентів-хореографів освітнього рівня "бакалавр" [9: 165-174].

Зокрема, зосередимо дослідницьку увагу на специфіці формування тих якостей професії, що характеризують як балетмейстерські (постановочні), так і суто педагогічні ії смисли, зміст яких сфокусовано в окремій категорії - "балетмейстер-педагог". Аналізуючи функційність балетмейстерського фаху в контексті дослідження діяльності його суб'єктів у конкретних соціокультурних і освітніх умовах, виокремлюємо його основні значення: 1) автор хореографії задля втілення ii у сценічних формах; 2) особа, що здійснюе навчання у галузі професійного танцю. Відповідно, серед сутнісних компетентностей професійної сформованості майбутнього балетмейстерапедагога (особистісних і фахових) домінантними є: 1) здатність до створення власного чи інтерпретації вже існуючого хореографічного продукту; 2) готовність до продуктивної хореографічно-педагогічної діяльності у професійній та соціально-культурній сферах. Тож, уважаємо, майбутній балетмейстер, освоївши виконавську і творчо-постановочну сценічну діяльність, повинен також володіти арсеналом загальнопедагогічних умінь, а відтак, підготовка балетмейстера-педагога в умовах вищої хореографічної освіти має забезпечувати розвиток професійних компетентностей в інтегрованому руслі - в галузі загальної і хореографічної педагогіки.

Необхідність інтеграції загальнопедагогічних і вузькопрофесійних завдань вищої хореографічної освіти доводять сучасні теоретики і практики галузі професійної хореографії. Зокрема, С. Забредовський, аналізуючи актуальні тенденції, проблеми і перспективи розвитку хореографічної освіти, наголошує на важливості грунтовної педагогічної підготовки майбутніх фахівців-хореографів: "Сьогодні мало хто асоціює професію хореографа з професією вчителя, викладача ... У хореографічній практиці люди, які мають досвід артистичної й виконавської роботи, часто намагаються працювати керівниками хореографічних колективів, як педагоги, проте, викладачами стають одиниці. Сьогодні викладач - це не тільки людина високої культури 3 хорошою професійною підготовкою, а ще й особистість, яка має ... серйозний багаж педагогічних знань" [10: 35]. У цьому ж контексті російський дослідник В. Нікітін зазначає, що важливу роль у професійній підготовці хореографа відіграє саме "формування педагогічних навичок та вмінь, оскільки хореограф є не лише автором мистецького твору, але й педагогом", акцентуючи при цьому на необхідності володіння майбутнім фахівцем насамперед "педагогічними прийомами задля передачі своїх ідей, творчих задумів виконавцям та учням у процесі професійної діяльності" [11: 6-7]. Доводячи особистісно-орієнтований характер вищої хореографічної освіти, вчений додає, що "головною педагогічною задачею професійної підготовки хореографа $\epsilon$ розкриття індивідуальності, виховання хореографа-творця, що володіє високим інтелектом, конвергентним, абстрактним і парадоксальним мисленням, вільно володіє способами самобутнього вираження свого внутрішнього світу через індивідуальну форму руху" [11: 7]. Отже, у формуванні змістового наповнення фахової підготовки майбутнього балетмейстера-педагога необхідною умовою вважаємо інтеграцію загальнопедагогічних ідей з концептами сучасної хореографічної педагогіки, активним застосуванням в освітньому процесі як вузькопрофесійних (хореографічних), так і педагогічних методик, технологій.

На основі дослідження колегіального та власного професійно-практичного досвіду підготовки фахівців-хореографів у вищому навчальному закладі зазначимо, що професійні компетентності, як правило, не можуть бути цілком сформовані у студентів-хореографів у межах вивчення окремої навчальної дисципліни. Цей процес $є$ системним і міждисциплінарним, а зміст кожного курсу має 
забезпечувати комплексний характер підготовки фахівця. Враховуючи, що специфіка хореографічної діяльності у первинному значенні полягає в руховому відтворенні ідейного задуму твору засобами тіла i акторської гри, інтегральною для всіх фахівців-хореографів компетентністю $є$ вільне володіння хореографічною лексикою різновидів сценічного танцю (класичного, народно-сценічного, спортивного бального, історико-побутового, сучасного сценічного), здатність створювати складні танцювальні композиції з різноманітних танцювально-пластичних елементів і окремих частин, які утворюють цілісну єдність, готовність демонстрації власної хореографічно-виконавської культури. Зазначена компетентність, що формує досвід передовсім танцівника-виконавця, включає в себе різні види кінетичної активності, а також методики та технології впливу на об'єкт професійної діяльності 3 метою його професійного перетворення.

Володіння професійно-практичним досвідом створювача, постановника, реставратора танцювального твору відбувається під час опанування курсів, які сфокусовані на формуванні зазначених фахових якостей балетмейстера, серед них: "Підготовка концертних номерів", "Композиція і постановка танцю", "Теоретичні засади режисури культурно-мистецьких проектів", "Мистецтво балетмейстера". Зокрема, програмні результати навчання 3 означених дисциплін відбивають єдність теоретичної і практичної готовності балетмейстера-педагога до професійної діяльності і включає в себе сукупність спеціальнопредметних знань, виконавських умінь, особистісних характеристик, як-от: знання видів, форм, жанрів хореографічного мистецтва; розуміння основних законів драматургії та готовність їх застосувати в хореографічній діяльності; здатність сприймати хореографічний твір як мистецьке явище, розуміння його художньої своєрідності, особливостей балетмейстерського стилю; здатність розглядати хореографічний твір в контексті розвитку загальної хореографічної культури; знання принципів роботи балетмейстера зі створення хореографічного образу; володіння основними принципами розбору танцю за записом, створення танцювальних етюдів, сюжетних і безсюжетних танців; готовність працювати над постановкою цілісних концертних програм, культурно-мистецьких проектів.

Важливою компетентністю балетмейстера-педагога вважаємо також здатність до управлінської діяльності у системі професійної і додаткової мистецької освіти: управління хореографічним колективом, організаційно-творчої роботи з вихованцями колективу, організаційно-виховної - $з$ батьками вихованців, творчої співпраці та співтворчості - 3 колегами-хореографами. Формування у майбутнього балетмейстера-педагога якостей хореографічного менеджменту, як запорука його успішної професійної реалізації з урахуванням різних соціокультурних і освітніх умов, регламентовано у змісті дисциплін, які розкривають специфіку, стратегії, методики організаційно-творчої роботи 3 хореографічними колективами різних видів у мистецькій, культурно-освітній чи культурно-дозвіллєвій галузях. Крім навчальних курсів, спрямованих на підготовку студентів до здійснення управлінської діяльності (серед яких - "Методика роботи 3 хореографічним (дитячим хореографічним) колективом", "Хореографічний ансамбль", "Організація культурно-масових заходів"), здатність до самостійного керівництва хореографічними об'єднаннями різних типів і видів формується у процесі проходження виробничих практик.

Аналіз змістового навантаження професійно-практичної підготовки балетмейстера-педагога в умовах вищої хореографічної освіти дозволяє зазначити, що організація навчального процесу має бути максимально наближеною до умов майбутньої професії, а отже, відбуватися передусім у площині художньо-творчої активності студентства. Зокрема, на думку сучасних дослідників (Л. Макарової, М. Юр'євої) "специфіка хореографічної діяльності, іiі приналежність до сценічності визначають нестандартність професійної підготовки студента-хореографа. Зміст професійної хореографічної освіти зводиться не тільки до наукових знань, а включає емоційно-образний світ мистецтва, історичні традиції й сучасні інновації, ціннісні орієнтації й відносини, особистісні творчі прояви й сукупність видів хореографічної діяльності" [8: 50-51]. Укажемо, що зазначена характеристика освітнього процесу має об'єднувати всі змістово-організаційні форми хореографічного освіти в умовах вищого навчального закладу. Адже важливо, коли процес формування професійних компетентностей студента-хореографа здійснюється в цілісному мистецько-педагогічному середовищі, що загалом сприяє формуванню естетичної спрямованості та ціннісних орієнтацій особистості, здатності до художнього освоєння дійсності, особистісному творчому прояву і самовираженню в різних видах хореографічної активності.

Висновки та перспективи подальших досліджень. Отже, у результаті здійсненого аналізу окресленої проблеми зазначимо, що компетентність балетмейстера-педагога - багаторівнева, інтегральна характеристика особистісних і хореографічно-професійних якостей, що органічно поєднує сукупність загальнокультурних, загальнопедагогічних, вузькопрофесійних знань і умінь. Компетентнісний підхід до фахової підготовки майбутнього балетмейстера-педагога у структурі вищої хореографічної освіти забезпечує його готовність і здатність до продуктивної діяльності у вузькопрофесійній та соціокультурній сферах. Перспективними напрямами подальших досліджень з окресленої проблематики може бути деталізація форм, методів, традиційних та інноваційних технологій формування професійних компетентностей у представників хореографічних спеціальностей в умовах вищої освіти, а також 
активізація теоретико-методологічних розробок з упровадження профільних навчальних курсів, що відповідали б актуальним викликам хореографічної педагогіки, забезпечуючи конкурентоздатність випускника-хореографа на сучасному ринку праці.

\section{СПИСОК ВИКОРИСТАНИХ ДЖЕРЕЛ ТА ЛІТЕРАТУРИ}

1. Балет : Энциклопедия / [под ред. Ю. Н. Григоровича]. - М. : Сов. энцикл., 1981. - 623 с. : илл. - Библиогр. : C. $617-620$.

2. Колногузенко Б. М. Види мистецтв і хореографії / Б. М. Колногузенко / Національна хореографічна спілка України. - Харків, 2014. - 319 с. : іл.

3. Павлюк Т. С. Українське балетмейстерське мистецтво другої половини ХХ ст. : автореф. дис... канд. мист. 17.00.01 "Теорія та історія культури" / Т. С. Павлюк. - Київ : Держ. акад. керів. кадрів культури і мистецтв, 2005. $-20 \mathrm{c}$

4. Шамрова О. А. Особенности профессиональной подготовки руководителей хореографических коллективов [Электронный $\quad$ ресурс] О. А. Шамрова. http://www.rusnauka.com/10._ENXXIV_2007/Pedagogica/21814.doc.htm. - Заглавие с экрана.

5. Пархоменко О. М. Формування балетмейстерських умінь майбутніх учителів хореографії у процесі фахової підготовки : автореф. дис ... канд. пед. наук : 13.00 .04 "Теорія і методика професійної освіти" / О. М. Пархоменко. - Київ, 2016. - 20 с.

6. Митакович Л. А. Подготовка будущих педагогов-хореографов к решению профессиональных задач / Л. А. Митакович // Известия Российского государственного педагогического университета им. А. И. Герцена, 2009. - № 116. - С. 185-189.

7. Юрьева М. Н. Повышение квалификации педагога-хореографа : компетентность и развитие / М. Н. Юрьева, Л. Н. Макарова // Вестник ТГУ. Серия : Гуманитарные науки. - 2011. - № 12. - С. 108-113.

8. Юрьева М. Н. Компетентностная модель выпускника-хореографа / М. Н. Юрьева, Л. Н. Макарова // Высшее образование сегодня. - 2010. - № 4. - С. 50-53.

9. Мартиненко О. В. Формування професійної компетентності майбутніх учителів хореографії в умовах вищого навчального закладу / О.В. Мартиненко // Проблеми підготовки сучасного вчителя : [збірник наукових праць Уманського державного педагогічного університету імені Павла Тичини] / [ред. кол. : Безлюдний О. І. (гол. ред.) та ін.]. - Умань : ВПЦ Візаві, 2015. - Випуск 12. - С. 165-173.

10. Забредовський С. Г. Методика роботи 3 хореографічним колективом : [навч. посіб.]. Видання друге, доповнене. - К. : НАКККіМ, 2011. - 188 с.

11. Никитин В. Ю. Профессионально-педагогическая подготовка балетмейстера в учебных заведениях культуры и искусств : автореф. дис. док. пед. наук : 13.00.08 "Теория и методика профессионального образования" / В. Ю. Никитин. - М., 2007. - 49 с.

\section{REFERENCES (TRANSLATED \& TRANSLITERATED)}

1. Ballet [Ballet] : Entsiklopediia / [ed. by Yu. Grigorovich]. - M. : Sov. Entsikl., 1981. - 623 s. : ill. - Bibliogr. : P. 617-620.

2. Kolnohuzenko B. M. Vydy mystetstv i khoreohrafii [Types of Art and Choreography] / B. M. Kolnohuzenko / Natsional'na khoreohrafichna spilka Ukrainy [National Choreographic Union of Ukraine]. - Kharkiv, 2014. 319 s. : il.

3. Pavlyuk T. S. Ukrains'ke baletmeisters'ke mystetstvo drugoi polovyny XX st. [Ukrainian Choreography Art of the Second Half of the Twentieth Century] : avtoref. dys... kand. myst. 17.00.01 "Teoriia ta istoriia kul'tury" / T. S. Pavlyuk. - Kyiv : Derzh. akad. keriv. kadriv kul'tury i mystetstv, 2005. - 20 s.

4. Shamrova O. A. Osobennosti professional'noi podgotovky rukovoditelei khoreohraficheskikh kollektivov [Features of Professional Training of Heads of Choreographic Collectives] [Elektronnyi resurs] / O. A. Shamrova. - Rezhym dostupu : http://www.rusnauka.com/10._ENXXIV_2007/Pedagogica/21814.doc.htm. - Zaglaviie s ekrana.

5. Parkhomenko O. M. Formuvannia baletmeisterskykh umin' maibutnikh uchyteliv khoreohrafii u protsesi fakhovoi pidhotovky [Formation of Choreographer's Choreography Skills in Choreography in the Process of Professional Training] : avtoref. dys ... kand. ped. nauk : 13.00.04 "Teoriia i metodyka profesiinoi osvity" / O. M. Parkhomenko. - Kyiv, 2016. $-20 \mathrm{~s}$.

6. Mytakovych L. A. Podgotovka budushchykh pedagogov-khoreohrafov $\mathrm{k}$ resheniiu professionalnykh zadach [Preparation of Future Teachers-Choreographers for Solving Professional Problems] / L. A. Mytakovych // Izvestiia Rossiiskogo gosudarstvennogo pedagogycheskogo universiteta im. A. I. Gercena [A. I. Herzen Russian State Pedagogical University Journal], 2009. - № 116. - P. 185-189.

7. Yurieva M. N. Povysheniie kvalifikatsii pedagoga-khoreografa : kompetentnost' i razvitiie [TeacherChoreographer's Training : Competence and Development] / M. N. Yurieva, L. N. Makarova // Vestnyk TGU. Seriia : Gumanitarnyie nauky [Tomsk State University Journal of Philology]. - 2011. - № 12. - P. $108-113$.

8. Yurieva M. N. Kompetentnostnaia model' vypusknyka-khoreografa [Competence-Based Model of the GraduateChoreographer] / M. N. Yurieva, L. N. Makarova // Vyisshee obrazovanie segodnia [Higher Education Today]. 2010. - № 4. - P. 50-53.

9. Martynenko O. V. Formuvannia profesiinoi kompetentnosti maibutnikh uchyteliv horeografii v umovakh vyshhogo navchal'nogo zakladu [Formation of Future Teachers' Professional Competence of Choreography in Higher Education Institutions] / O. V. Martynenko // Problemy pidgotovky suchasnogo vchytelya [Problems of a Modern Teacher's Training] : [zbirnyk naukovykh prats' Umans'kogo derzhavnogo pedagogichnogo universytetu imeni Pavla Tychyny] / [red. kol. : Bezliudnyi O. I. (gol. red.) ta in.]. - Uman' : VPCz Vizavi, 2015. - Vypusk 12. - P. 165-173. 
10. Zabredovskyi S. G. Metodyka roboty z khoreografichnym kolektyvom [Working Procedure with Choreographic Team] : [navch. posib.]. - Vydannia druge, dopovnene. - K. : NAKKKiM, 2011. - $188 \mathrm{~s}$.

11. Nikitin V. Yu. Professional'no-pedagogicheskaia podgotovka baletmeistera v uchebnykh zavedeniiakh kul'tury i iskusstv [Professional-Pedagogical Training of the Choreographer in Educational Institutions of Culture and Arts] : avtoref. dys. dok. ped. nauk : 13.00.08 "Teoriia i metodyka professional'nogo obrazovaniia" / V. Yu. Nikitin. - M., 2007. $-49 \mathrm{~s}$.

\section{Благова Т. А. Формирование профессиональных компетентностей балетмейстера-педагога в структуре высшего хореографического образования: теоретический аспект.}

В статье исследованы сущзностные признаки профессии балетмейстера, их педагогическая ресурсность, основные содержательные направления профессиональной активности. Охарактеризован комплекс профессиональных компетенций и личностных качеств балетмейстера-педагога, необходимых

для успешной творческой самореализачии в различных формах профессиональной деятельности; намечены пути их формирования у студентов хореографических специализаций в структуре высшего хореографического образования.

Ключевые слова: балетмейстер, балетмейстер-педагог, хореограф, хореографическое образование, хореографическая педагогика, принципь балетмейстерского творчества, исполнительский стиль, хореографическо-педагогическая деятельность.

\section{Blagova T. O. Formation of the Choreographer-Teacher's Professional Competence in the Structure of Higher Choreographic Education: the Theoretical Aspect.}

The article gives a detailed analysis of the ballet-master's profession essential features, its pedagogical resource, the main content directions of professional activity and the ways of their formation among the students of choreographic specialization in the structure of higher choreographic education. According to the article the

study of this problem involved the use of such methods of search activity as content analysis, conceptualterminological analysis, comparison, synthesis and theoretical generalization. On the basis of its complex application, we have specified the essence of the "choreographer" category and the functional areas of professional activity of the choreographer specialty: creative, performing, performing, rehearsal, restoration, management, and pedagogical. The definition of choreography activity is proposed as a complex multidimensional phenomenon in the field of professional choreography, which is embodied in the process of multi-vector creative work with choreographic material. The dominant competencies of the professional formation of the future choreographer-teacher are the ability to create a choreographic work and readiness for productive choreographic and pedagogical activities in the professional and socio-cultural spheres. Modern formation tendencies of the training contents of the ballet-master-teacher in the conditions of higher education are analyzed and the significance of the competence approach to the organization of the educational process is theoretically substantiated.

Key words: ballet-master, ballet-master-teacher, choreographer, choreographic education, choreographic pedagogic, principles of ballet-master work, carrying out style, choreographic-pedagogical activity. 